\title{
Architektura neowernakularna - geneza. Od Erdmannsdorf do Pensjonatu „Maryja”
}

\author{
Jacek K. Knothe \\ Katedra Konserwacji Zabytków, Wydział Budownictwa i Architektury, \\ Politechnika Lubelska, e-mail: j.knothe@pollub.pl
}

Streszczenie: Na skraju architektury tworzonej przez architektów zawsze istniało zjawisko architektury ludowej. Stanowiło ono nie tyle przeciwieństwo architektury uznawanej za wybitną, co nurt architektury toczący się niezależnie własnym rytmem i życiem.

Określa się je mianem wernakularnego, z łaciny „vernaculus” oznaczający „rodzimy, ojczysty". Określenie to nie wyczerpuje jednak złożoności zjawiska; jest bowiem różnica pomiędzy architekturą wernakularną i samym zjawiskiem wernakularyzmu, a przede wszystkim neowernakularyzmem, czy też architekturą projektowaną współcześnie na tradycyjnych wzorcach, również nazywaną neowernakuarną ${ }^{1}$.

Uznaje się powszechnie, iż architektura wernakularna to „architektura bez architekta, anonimowa, powstająca bez projektu, wpisana $w$ tradycję społeczności i będaca suma doświadczeń budowlanych, funkcjonalnych i estetycznych przekazywanych z pokolenia na pokolenie"2. Kwestią pozostaje, czy określenie „powstająca bez projektu” oznacza, iż powstała ona historycznie bez projektu co czyniłoby ją wernakularną, czy nadal współcześnie powstaje w taki sposób, co musi stanowić o jej neowernakularności.

Polscy teoretycy i historycy architektury pojmują pojęcie architektury wernakularnej na różne sposoby; Adam Miłobędzki wskazuje na lokalną tradycję budowlaną i użycie miejscowych materiałów, a Joanna Fiett lokuje ją pomiędzy architekturą prymitywną a autorską, kładąc nacisk na aspekt powielania i odtwarzania pewnego pierwowzoru uznanego za dzieło sztuki. Żadne z tych autorów nie zajmuje się, a tym bardziej nie ocenia, wartości architektury neowernakularnej z uwzględnieniem jej wtórności, uznając ją za prawie równie autentyczną co jej wernakularny wzór.

Architektura wernakularna - rdzenna, kopiując wzór historyczny postrzegany jako dzieło sztuki, sama jednak na takie miano nie zasługuje, tym bardziej więc na miano dzieła sztuki nie zasługuje architektura neowernakularna, nie odmawiając jej wartości artystycznych, historycznych i niewątpliwego uroku.

Nie wnikając w niuanse uważa się bezzasadnie, że architektura wernakularna to po prostu tradycyjne budownictwo regionalne, a uznając że powstało jako praca autorów bez przygotowania akademickiego, uważa się wernakularyzm po prostu za kierunek swobodnie czerpiący z architektury wernakularnej, bez drobiazgowego wyodrębniania wernakularyzmu „konserwatorskiego” oraz ,interpretatywnego” neowernakularyzmu. Pierwszy z nich to jednak nic innego jak kontynuacja działań poprzednich pokoleń, to jest podtrzymywanie i wykorzystywanie tradycyjnych rozwiązań i materiałów, drugi jednak zakłada dostosowa-

\footnotetext{
${ }^{1}$ Turkušić E., „Neo-vernacular architecture - contribution to the research on revival of vernacular heritage through modern architectural design", 2011, Conference: "Importance of Place - 4th International Conference on Hazards and Modern Heritage", University of Sarajevo.

2 Kurzątkowski M., Architecture vernaculaire = architektura rodzima?, Ochrona Zabytków, nr 1(158), s.3.
} 
nie architektury wernakularnej do nowych funkcji i potrzeb, a tym samym czyni z niego architekturę neowernakularną.

Proweniencja przeważającej części architektury wernakularnej na terenie Europy środkowej, w tym i obecnych terenów Polski, była szwajcarska (alpejska) i jej dotyczy niniejsze opracowanie.

Pod koniec XIX wieku, a więc nieco później niż w przypadku alpejskiej architektury wernakularnej, nastąpił na terenie zaborów rozwój architektury podmiejskiej, realizowanej przez M. E. Andriolli'ego ${ }^{3}$ w okolicach Warszawy w latach 1880-1890 w ramach ruchu wilegiatury, jednak o odmiennym niż alpejski pierwowzorze. Choć miała w sobie koloryt alpejskich kurortów, czerpała wzorce raczej z architektury daczy z okolic podmoskiewskiej Wiatki $^{4}$, gdzie M. E. Andriolli przebywał na zesłaniu ${ }^{5}$.

Zakres wpływu, jaki na nią wywarła alpejska architektura wernakularna stanowi odrębne opracowanie autora.

Słowa kluczowe: Gründerzeit, Gründer, historyzm, eklektysm, neostyl, wernakularny, neowernakularny.

\section{Wernakularyzm i neowernakularyzm - różnice}

Dowolność terminologii języka potocznego przeniknęła do języka naukowego, w którym zwykle nie odróżnia się wernakularyzmu od neowernakularyzmu oraz nie różnicuje się wernakularnych stylów alpejskich oraz ich uwarunkowań i charakterystycznych cech. Diagnozę tego zjawiska postawił i w sposób wyczerpujący opisał J. Tarnowski, i niniejsze opracowanie w pewnym zakresie odwołuje się do jego pracy ${ }^{6}$.

W nazewnictwie stylu szwajcarskiego, zarówno niemieckojęzycznym jak i polskim, nie było od początku jak i obecnie, konsekwencji, i określenie stylu szwajcarskiego odnoszone jest zarówno do architektury ludowej w jej formie czystej i oryginalnej - wernakularnej, jak i neowernakularnej, a więc przetworzonej. Wraz z pojawianiem się w Europie architektury w stylu szwajcarskim, pojawiły się dosłowne ekwiwalenty niemieckojęzycznych określeń stylu „tyrolskiego”, „szwajcarskiego” i „,alpejskiego”, a także ich odmiany pejoratywne, typowe dla sytuacji gdy styl lub obyczaj postrzega się jako narzucony lub obcy $^{7}$.

Formy i kanony architektury, również tej wernakularnej, zwykle zmieniały się ewolucyjnie (a więc w sposób zrównoważony), nie zaś poprzez rewolucję. Za taką przecież należałoby uznać importowanie i przetwarzanie na miejscu obcych, choćby najlepszych

3 Oktabiński K., Otwockie Towarzystwo Naukowo-Kulturalne, ,Michał Elwiro Andriolli - artysta południowo-wschodniego Mazowsza". M.E. Andriolli ur. w Wilnie 2 listopada 1836 r. w rodzinie Francesca Andriollego, pochodzącego z okolic Trydentu oficera armii napoleońskiej osiadłego w Wilnie.

4 W okresie ZSSR - miasto Kirów.

5 Janina Wiercińska w biografii artysty pt. „Andriolli, świadek naszych czasów - listy i wspomnienia", wyd. Wrocław 1976 r. Również: Karolina Beylin „Dni powszechne Warszawy w latach 1880-1890” „,Wymyślit nowy rodzaj konstrukcji ścian i jego zdobnictwa. Własnoręcznie rysowat na deskach ozdoby $i$ ornamenty, po czym zlecat ich wykonanie cieślom i stolarzom. W 1885 r. artysta okazyjnie zakupuje nastepne drewniane pawilony z warszawskiej wystawy techniczno-przemysłowej, które po przebudowie ustawił nad brzegami Świdra. Nowa kolonia miała służć kolejnym letnikom. Aby spopularyzować swoje przedsięwzięcie urzadza tam festyny, koncerty itp. "

6 Tarnowski J., Artykuły Styl alpejski w Środkowej Europie i polska kontrakcja wobec niego - styl zakopiański Estetyka i Krytyka 25 (2/2012).

7 wcześniej „włoszczyzna”, następnie „tyrolszczyzna”, szwajcarszczyzna” a później „grynderstwo”. 
nawet wzorów, a jej efekty, jak miało to miejsce w przypadku stylów dekoracyjnych jak Secesja, byłyby krótkotrwałe.

W przypadku architektury wernakularnej obserwacje i doświadczenia wcześniejszych pokoleń uwzględniają czynniki topografii, klimatu, światła czy tektoniki, stanowiąc o zgodności funkcji i formy. Zastosowanie lokalnych materiałów, powtarzanie i adaptacja detali i cech charakterystycznych, budują w społecznościach, budujących architekturę wernakularną poczucie ciągłości kultury materialnej, a szacunek wobec tradycji i historii umacnia poczucie tożsamości. To czyni architekturę wernakularną autentyczną i cenną, ale także autonomiczną, ingerencja w którą powoduje istotny dysonans poznawczy. Nie można nie zauważyć, że przekaz architekta - prowokatora, Rema Koolhaasa ${ }^{8}$, dla wielu współczesnych architektów stał się już nie przyzwoleniem a przykazaniem, i projektują oni dzieła, funkcjonujące niejako same w sobie, w oderwaniu od ducha i tradycji miejsca, nacechowane z pewnością indywidualnością i mogące istnieć (i prowokować) w każdym miejscu na świecie, lecz bez związku z duchem miejsca i bez oglądania się wstecz. Sam Koolhaas dostrzega sztuczność tego procesu i dystansuje się od niego ${ }^{9}$.

Reakcją na tę tendencję staje się obecnie rosnąca popularność postaw alterglobalistycznych i promocja idei „slow design”. Przybiera ona czasami wprawdzie formę neofolkloru lecz w naturalny sposób zwraca uwagę w kierunku architektury opartej na wzorcach ludowych, postrzeganych, zresztą niesłusznie, jako architektura wernakularna. Kwestia rzeczywistego udziału tej architektury w kształtowaniu współczesnego pejzażu architektonicznego nie stanowi zakresu tego opracowania.

Wczesny europejski neowernakularyzm, za którego przykład uznaje się dworek z parkiem i wsią Hameau de la Reine królowej Marii Antoniny w Versailles ${ }^{10}$ z 1774 roku, podobnie jak pałac F.W. von Reden'a, zrealizowany niewiele później w roku 1785 w Buchwald (Bukowiec) w Karkonoszach, oba o proweniencji stylowej niesłychanie zmelanżowanej, należały jeszcze do starego porządku polityczno - społecznego Europy. Późniejsze o 100 lat XIX wieczne neowernakularne obiekty demokratycznego już ruchu turystyczno - kuracyjnego Europy Środkowej należą już do ery nowoczesnej.

8 Koolhaas R., „Content”, 2004, Taschen.

9 Mackenzie A. ,wywiad z Remem Koolhaas nt. Biennale Architektury w Wenecji, Architecture Australia, marzec 2014 (Vol. 103 nr 2). „Przyglądając się uważnie można zobaczyć ogromny powrót nie wernakularnej, ale quasi wernkularnej architektury i quasi-stare fortece budowane współcześnie w duchu narodowym. Spójrz na (miasto - przypis autora) Zaandam , i to ogromne nagromadzenie budynków zwanych wernakularnymi. (....) Dobrze to rozumiem, ponieważ większość tzw. nowoczesnej architektury jest naprawdę rodzajem efekciarskiego (gimmicky) modernizmu, a to pozwala tradycjonalizmowi również być efekciarskim. (....) Widzę to mniej z architektonicznej perspektywy a bardziej z socjologicznej albo antropologicznej. Ostatnie lata widziały nadzwyczajny wzrost czegoś, co nazwałbym quasiwernakularnym, szczególnie na terenie Europy".

${ }^{10} \mathrm{~W}$ ogrodach Wersalu znajduje się założenie parkowo pałacowe, w skład którego wchodzą dwa pałace Grand Trianon i Petit Trianon oraz wioska królowej Marii Antoniny, Hameau de la Reine,. W 1774 roku Ludwik XVI ofiarował Petit Trianon swej żonie, Marii Antoninie, która z dala od etykiety dworskiej pałac i ogród urządziła na nowo. Park w stylu angielsko-chińskim nawiązywał do jej rodzinnego, alpejskiego krajobrazu. Z biegiem czasu ten tzw. Mały Wiedeń wzbogacił się o teatr, autorstwa Richarda Mique oraz o inspirowaną rustykalnymi widokami Chantilly wieś o 12 drewnianych chatach w stylu normandzko-flamandzkim, krytych strzechą. 


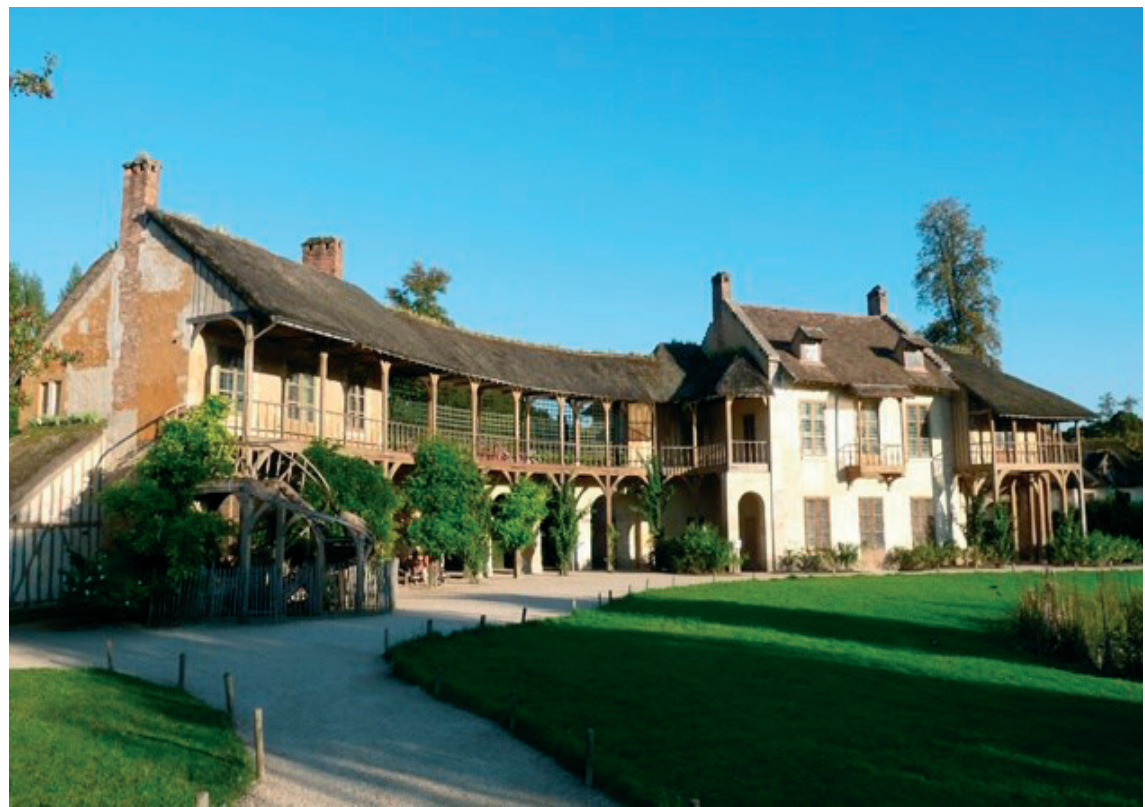

Fot. 1. Hameau de la Reine, Wersal (Versailles) 1774, autor Richard Mique autor fotografii Ewa Kimaszewska

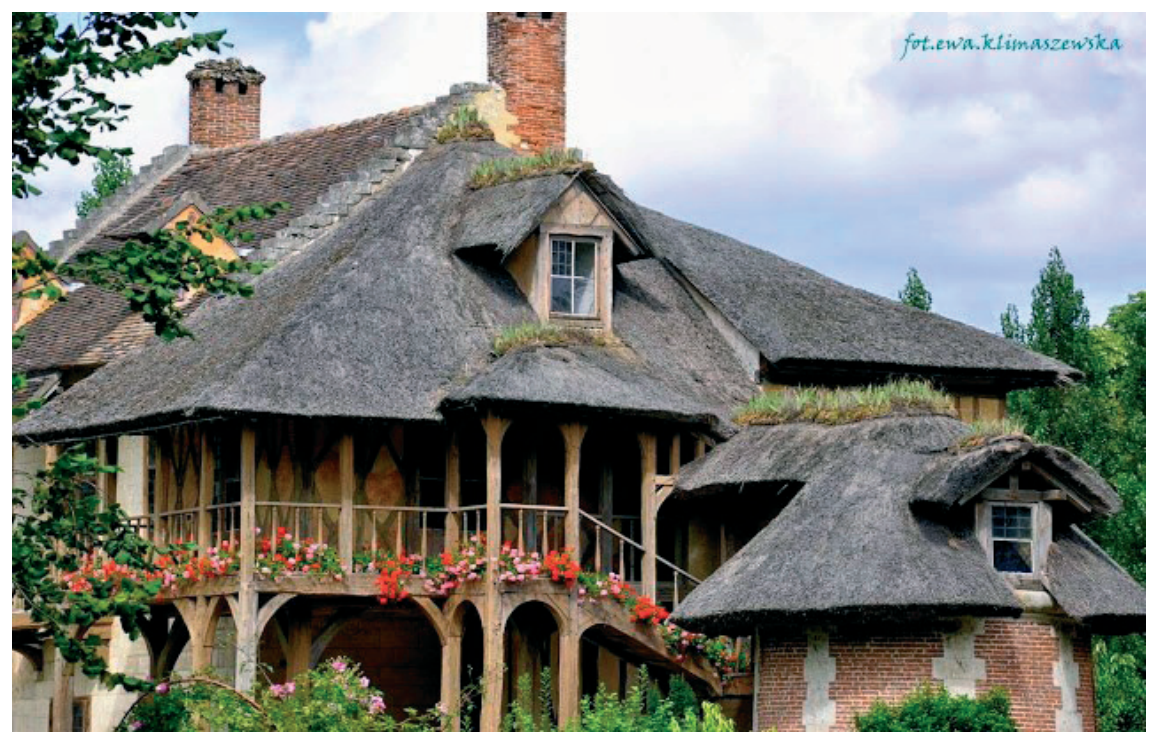

Fot. 2. Hameau de la Reine, Versailles 1774, arch. Richard Mique, architektura neowernakularna o wzorcu normandzkim, autor fotografii Ewa Kimaszewska

W Europie Środkowej XIX wieku obiektom neowernakularnym nie towarzyszyła początkowo aura nowoczesności, bo bazując na wzorach historycznych były postrzegane zaledwie jako drewniane uzupełnienie panującego wówczas historyzmu. Nowoczesność charakteru neowernakularyzmu stała się bardziej oczywista, gdy zaczął być utożsamiany z początkiem i przynależnością do świata kolei żelaznej, postępu technicznego i masowej 
turystyki. Idea nowoczesnej architektury neowernakularnej przyszła więc wraz z postępem technicznym z Anglii, której architekturę i gospodarkę postrzegano już wówczas jako nowoczesną ${ }^{11}$.

Pojawienie się współczesnego nam nurtu wernakularyzmu światowego nastąpiło świadomie w trakcie wystawy Architektura bez architektów w Nowym Yorku, w 1964 roku ${ }^{12}$. Prezentowane na niej budownictwo „trzeciego świata” zostało tam ukazane jako zarazem piękne i funkcjonalne, a budowle jako,,architektoniczne".

Wystawa przedstawiła architekturę wernakularną w formie paraleli do medycyny naturalnej i jej harmonii z naturą, a prezentowane poglądy przypadły na koniec boomu gospodarczego po II wojnie, i początku poszukiwań naturalnego kontekstu w architekturze. Początek lat 60.tych był okresem ostatecznego zaniku formuły kolonializmu, a najostrzejsze deklaracje narodowościowe były widoczne w krajach, które w połowie XX wieku odzyskały niepodległość, m. in. w Egipcie, Indiach, krajach arabskich i Ameryce Południowej. Pochodzący stamtąd architekci, wykształceni w stolicach krajów kolonialnych, Londynie i Paryżu, po repatriacji zaczęli poszukiwać swoich rdzennych korzeni. ${ }^{13}$

Krokiem milowym w badaniach i dokumentacji architektury wernakularnej była wydana w 1997 roku „Encyklopedia architektury wernakularnej świata” pod redakcją Paula Olivera $^{14}$, do zebrania materiałów której włączono 250 naukowców z 80 krajów.

\section{Alpejski rodowód wernakularyzmu}

Nowy styl w XIX wiecznej architekturze miejscowości kuracyjnych, bazujący na ludowych, to jest wernakularnych wzorach budowania różnych regionów, rozwijał się praktycznie we wszystkich krajach Europy Środkowej. W zależności od lokalizacji obiektu lub źródła impulsu do jego powstania, a nie z powodu różnic formalnych czy stylowych, bo w zasadzie takich się nie doszukiwano i nie dostrzegano, identyfikowano je albo jako szwajcarskie, albo jako tyrolskie.

Z czasem styl stawał się neowernakularny a w skrajnych przypadkach eklektyczny; czerpał formy z wielkich stylów historycznych i mieszał się z historyzmem, zwykle z nadal widoczną dominantą form budownictwa alpejskiego.

Z pojawieniem się zjawiska ruchu turystycznego, architektura wernakularna obszaru Alp, początkowo Szwajcarii a potem Tyrolu i Bawarii, zaczęła stawać się inspiracją dla obiektów o odmiennych już funkcjach; sanatoriów, hoteli, pensjonatów i schronisk zwykle, choć nie zawsze, asocjowanych z ideą rozwijającej się właśnie XIX wiecznej turystyki masowej.

Formy rodzimej architektury ludowej były w Szwajcarii kultywowane i przetwarzane już od końca XVI wieku ${ }^{15}$, nieco później w Tyrolu, chociaż długo jeszcze, bo do przełomu XIX i XX wieku sprowadzały się do budownictwa chłopskiego, o różnej zresztą funkcji.

${ }^{11}$ Dał temu trybut Eugène Viollet-le-Duc, wychwalając w książce Habitations modernes (1875) zrealizowaną w latach 1870-72 przez Richarda Normana Shawa podlondyńską rezydencję Grim's Dyke.

${ }^{12}$ Nowy York, Metropolitan Museum of Modern Art., 1964. Pod tym samym tytułem co wystawa została również wydana książka, autorstwa Bernharda Rudofsky'ego, kustosza wystawy.

${ }^{13}$ Prekursorem tego kierunku stał się egipski architekt i poeta Hasan Fathy, którego wystawa rysunków w Kairze w 1938 roku prezentowała architekturę egipską jeszcze przedkolonialną, i którego projekt osady Nowa Gurna z 1947 roku połączył tradycje ze współczesnymi wymogami kulturowymi i funkcjami, unikając jednak tworzenia repliki miasteczka egipskiego.

${ }^{14}$ Oliver P., Encyclopedia of Vernacular Architecture of the World, 1997 Vol. 1 Theories and Principles, Cambridge University Press 1998. 
Spośród trzech funkcjonujących w obiegu terminów opisujących rdzenną architekturę z obszaru Alp najbardziej odpowiednim wydaje się być „alpejski”, bo terminy „tyrolski” i „szwajcarski” mają zbyt wąskie znaczenie, odnosząc się tylko do fragmentów obszaru występowania, w rzeczywistości będąc obecne na całym pogórzu i terenie Alp. Można uznać, że alpejskość stanowi synonim stylu rozprzestrzeniającego się niezależnie od granic lub ich braku. Jak pisze B.M. Pawlicki „Dawne, ewoluujace w ciagu wieków idee, kształtujące przez tysiaclecia wybitne dzieła sztuki, postać techniki, formy $i$ plany wytworów urbanistyki, a także szatę zewnętrzna architektury zależaly od otwartości lub introwersji granic, zbliżenia lub osamotnienia cywilizacyjnego $i$ kulturowego, $w$ zamykaniu lub rozprzestrzenianiu się kręgów kulturowych"16.

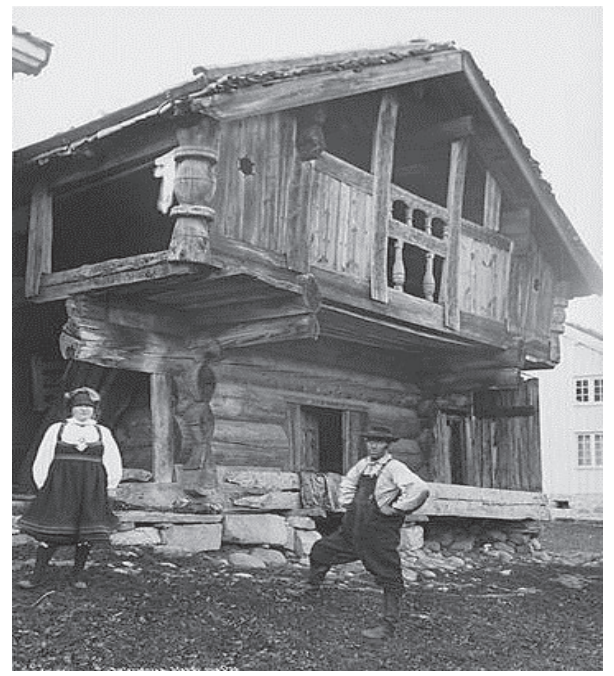

Fot. 3. Wernakularna architektura z obszaru Alp, autor nieznany. Autor fotografii: nieznany

Z takim definiowaniem pochodzenia, a tym bardziej nazewnictwem, w przypadku alpejskiej architektury wernakularnej należy być ostrożnym, gdyż to jednak w kantonach Szwajcarii najszybciej rozpoczął się proces przekształcania form ludowych i transplantowania ich do budownictwa o innej funkcji. Należy podkreślić, że gdy architektura powstających kurortów Europy XIX wieku czerpała inspirację rodem z Alp, to korzystała z już przetworzonych wzorów szwajcarskiego neowernakularyzmu a nie czystych form wernakularnych, z tego też powodu przypisywanie jej raczej terminu „szwajcarski” wydaje się być logicznie uzasadnione.

Nie odrzucając powyższej argumentacji trzeba uznać termin „,budownictwo alpejskie” za bardziej uniwersalny, chociaż dotyczący głównie wernakularnego budownictwa ludowego niemieckojęzycznej części Alp, położonych na obszarze obecnej Austrii (tj. w jej części

\footnotetext{
${ }^{15}$ Pierwszym naukowym opracowaniem architektury szwajcarskiej wzorowanej na ludowym budownictwie alpejskich górali była książka Ernsta Gladbacha Der Schweizer Holzstil (1882). Najstarszy obiekt tego typu przedstawiony w tym dziele datowany jest na rok 1586.

${ }^{16}$ Pawlicki, Bonawentura M. „Architektura bez granic - peryferyjność czy uniwersalizm” Zakład Studiów i Badań Konserwatorskich, Instytut Historii Architektury i Konserwacji Zabytków Wydział Architektury, Politechnika Krakowska Teka Kom. Arch. Urb. Stud. Krajobr. - OL PAN, 2007, 107-116
} 
wschodniej i centralnej - Tyrolu), włoskiego Tirolo ${ }^{17} \mathrm{w}$ ich części południowej, w całości Szwajcarii i Niemiec - w części północnej Alp.

Alpejska architektura wernakularna pozbawiona jest zatem ściśle określonego pedigree - rodowodu w rozumieniu dziedziczenia cech określonych przodków ${ }^{18}$. Stosowane do niej były trzy różne synonimy określeń; brzmiące w niemczyźnie Schweizer Stil, Tiroler Stil, Alpenländischen Stil, a wszystkie odnoszące się do budownictwa ludowego rejonu Alp.

Alpejskie budownictwo ludowe z jednej strony sprowadzało się do powtarzania uznanych wzorców i konstrukcji prostych obiektów gospodarskich, z drugiej do budowy wielofunkcyjnych zagród chłopskich w dwóch wariantach: budynków o funkcji czysto mieszkalnej oraz budynków o mieszanej funkcji mieszkalno-gospodarskiej. Podczas gdy budynki mieszkalne były na rzucie kwadratu, a w przypadku funkcji mieszanej były na planie mocno wydłużonego prostokąta - to jednak oba typy miały wspólną cechę - jednolity (dwu lub wielospadowy) dach, kryjący wszystkie części budynku. Taki dach stosowano później w architekturze XIX wieku wielokrotnie w obiektach o czasami skrajnie innej formie, chcąc nadać im cechy rustykalne.

Budynki wznoszono z drewna, zwykle o konstrukcji zrębowej; przykrywano je dwuspadowym dachem ze znacznie wysuniętym okapem, krytym dranicami, uzyskiwanymi w wyniku rozwarstwiania bali drewnianych. Rozległy dach stanowił konstrukcję wystarczająco solidną dla przeniesienia znaczących obciążeń od śniegu, który przy nieznacznym kącie pochylenia połaci (zwykle 25-30\%) zalegał na nich przez cały sezon zimowy stanowiąc dodatkową izolację termiczną w surowym klimacie.

Okapy podłużnych ścian tych budynków, dające balkonom osłonę przed śniegiem, podtrzymywane były zdobionymi końcami krokwi, na elewacji szczytowej krokwie dodatkowo wspierane były wysuniętymi płatwiami stolców oraz stężane i zdobione. Budynki, zwrócone zwykle ścianą szczytową do frontu nieruchomości, na całej jego szerokości oraz na ścianach bocznych pod okapem dachu posiadały drewniane balkony, chociaż niekiedy balkon otaczał tylko część mieszkalną. Ściany szczytowe budynków były często szalowane deskami, wraz z drewnianymi aplikacjami tworzącymi ich dekorację. Te wernakularne formy zachowały się dotąd w budynkach w Mysłakowicach (niem. Erdmannsdorf ), a na obszarze Alp są nadal powszechne współcześnie, już jako formy neowernakularne.

Późniejsze próby i sposoby nawiązywania do alpejskich pierwowzorów coraz bardziej się od nich oddalają i jedynymi cechami pozwalającymi na identyfikację stylową są wydatne dachy okapowe i podszczytowe balkony z ozdobnymi balustradami, a także - niewystępujące jednak w ludowych pierwowzorach - ażurowe dekoracje wyrzynane w desce. Dekoracje takie pojawiły się później, na pocz. XIX w., dzięki wynalezieniu pił cienko brzeszczotowych, pozwalających na ażurowe wycinanki w drewnie. Od niemieckiej nazwy die Laubsäge (szybko spolszczonej na „laubzega”) upowszechniła się też ironiczna nazwa tej architektury - Laubsägenarchitektur, sugerująca - jeśli tylko była odnoszona do obiektów w stylu alpejskim - że te właśnie laubzegowe dekoracje są ich głównym elementem wyróżniającym. Dekoracja ta nie odpowiadała wprawdzie wernakularnym pierwowzorom, ale stała się dodatkowym upiększeniem alpejskiego neowernakularyzmu. Obiekty tego typu i o takim zdobnictwie, o różnej zresztą proweniencji, budowane były także z dala od rejonów górskich, na terenach Polski w Ciechocinku, w Międzyzdrojach i w okolicach Warszawy.

\footnotetext{
${ }^{17}$ Tyrol należał do Austro - Węgier do ich rozpadu wskutek I wojny światowej, południowa część Tyrolu znalazła się w granicach Włoch dopiero po 1918 roku.

${ }^{18}$ Oryginalnie - pied de grue - noga żurawia, odwrócona - graficznie symbolizuje pochodzenie od jednego pnia.
} 
Architektura inspirowana budownictwem alpejskim z upływem czasu coraz bardziej oddalała się od ludowych pierwowzorów i pod koniec XIX wieku jej bardziej eklektyczne nurty zaczęły zatracać swoją tożsamość genetyczną. Na tyle jednak różniły się nadal od wielkomiejskiej architektury stylów historyzmu, że identyfikowano je jeszcze jako ,alpejskie" (szwajcarskie, tyrolskie) ${ }^{19}$. Stały się malowniczą architekturą miejscowości turystycznych i kuracyjnych, harmonijnie zintegrowaną z krajobrazem, tworzącą z nim nową synergiczną wartość estetyczną. Ten związek architektury z krajobrazem pozwala traktować je jako mutację czy rodzaj, w zmniejszonej skali, romantycznych koncepcji założeń pałacowo-parkowych.

\section{Karkonosze - kolebka wernakularyzmu alpejskiego}

Alpy, z powodu nierozwiniętej komunikacji, były dla Europy nieoczekiwanie miejscem dość odległym i trudno dostępnym, i chociaż stamtąd pochodziły wzorce, to nie tam decydowały się losy europejskiej wernakularnej architektury ludowej. Miejscem tym, z wyjątkiem budownictwa Szwajcarii realizowanego na własny użytek, paradoksalnie stały się nie Alpy lecz Karkonosze (niem. Riesengebirge), które już w XVIII wieku zaczęły zmieniać swój kulturowy charakter.

Po zajęciu ich wraz z Dolnym Śląskiem w roku 1740 przez Prusy, obszar Karkonoszy eksploatowany był, podobnie jak w okresie przynależności do Austrii, jako obszar intensywnej eksploatacji leśnej i górniczej.

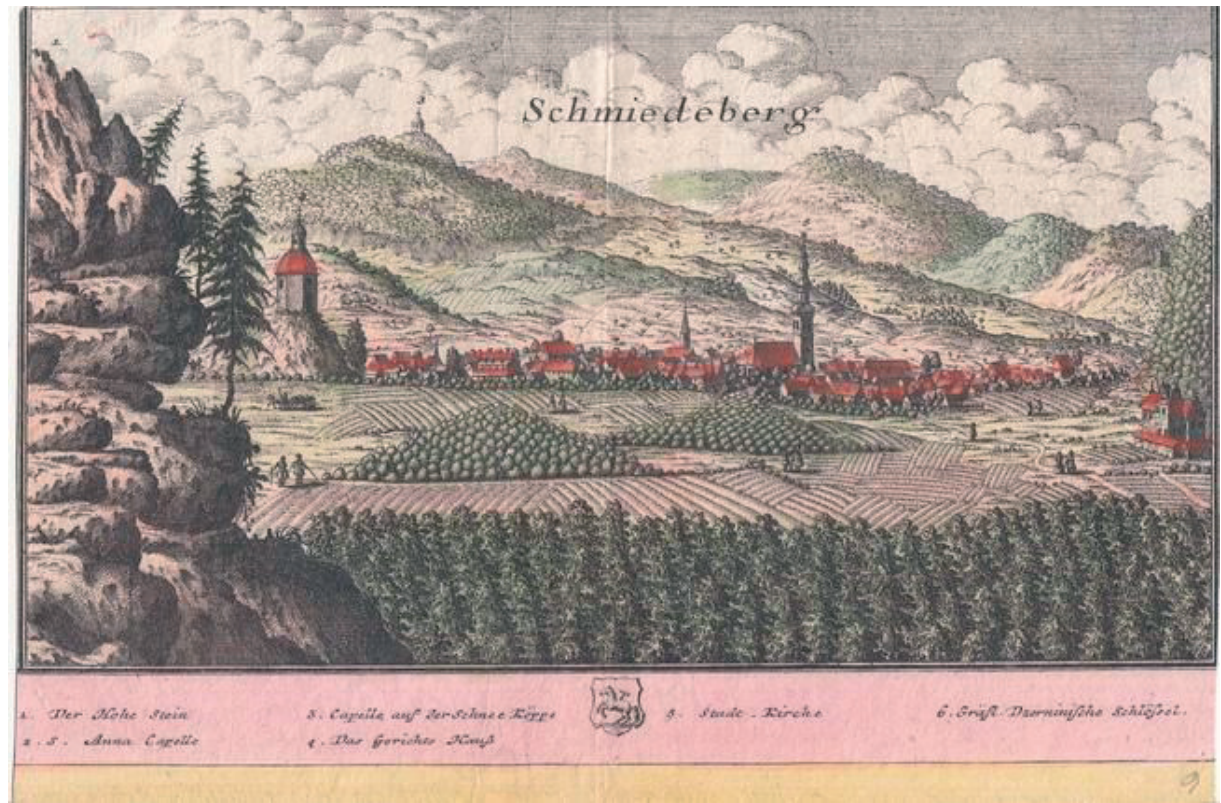

Ryc. 1. Widok na Śnieżkę (niem. Schneeberg) z Kowar (niem. Schmiedeberg), Miedzioryt autor: Friedrich Bernhard Werner, 1738

Pod koniec XVIII wieku podnóże Karkonoszy, czyli Kotlinę Jeleniogórską, odkryła arystokracja pruska jako stosowną dla wznoszenia letnich rezydencji, same zaś góry zyska-

\footnotetext{
${ }^{19} \mathrm{~W}$ takich przypadkach pojęcie stylu traci ścisły sens, więc słowo brane jest w cudzysłów.
} 
ły wyjątkową rangę w pruskiej kulturze romantycznej, podobną do rangi Alp w romantyzmie zachodnioeuropejskim, łącząc najcenniejsze dla romantyzmu walory: tajemniczość, egzotykę, dzikość, ludowość i monumentalność.

Region i same góry Karkonosze od końca XVIII wieku były celem peregrynacji arystokratów, w tym koronowanych głów, wzbogaconego mieszczaństwa oraz artystów. Odkąd na Śnieżkę (niem. Schneekoppe) weszli w 1790 roku Johann Wolfgang Goethe, a w 1800 roku królowa pruska Luiza z mężem, królem Fryderykiem Wilhelmem III $^{20}$, góra ta jak i cały obszar Karkonoszy, nazywany w niemieckiej literaturze romantycznej śląskim Elysium i Pruską Arkadią ${ }^{21}$, stała się dla pruskich elit obowiązkowym celem romantycznych podróży, równie kultowym jak zamek krzyżacki w Malborku. Za pierwsze schroniska służyły budy pasterskie, zaś na samej Śnieżce od 1824 roku do czasu wybudowania schroniska w 1850 roku funkcję taką pełniła kaplica św. Wawrzyńca, zbudowana przez hr. L.Ch. Schaffgotsch'a w 1665 roku $^{22}$.

W II połowie XIX wieku coraz większego znaczenia w architekturze Prus, a następnie Niemiec, nabierały obiekty, które w czytelny dla współczesnych sposób dostarczały poszukiwanej i pożądanej tożsamości narodowej i kulturowej, której brakło zarówno Prusom będącym do 1871 roku jedynie jednym z królestw, jak i Austro - Węgrom, czy raczej Monarchii Habsburgów, stanowiącej konglomerat kultur. Potrzeba takiej tożsamości miała oczywisty związek z przemianami społecznymi stanowiących skutek wcześniejszej Wiosny Ludów z 1848 r.

Dla architektury Europy nadchodził czas historyzmu; po śmierci Fryderyka Wilhelma III w 1840 roku, następca tronu pruskiego, Fryderyk Wilhelm IV, zlecił F.A. Stüler'owi, kontynuatorowi prac zmarłego wkrótce K. F. Schinkla, przekształcenie wystroju pałacu w Mysłakowicach (niem. Erdmannsdorf) na styl neogotycki.

Równocześnie z przebudową pałacu wzniesiono w jego sąsiedztwie pałacyk dla księżnej Legnicy ${ }^{23}$, która odsprzedała następcy tronu całą rezydencję. Podobnie jak willa von Rother'a, pałacyk wzorowany był (a więc neowernakularny) na domach tyrolskich $\mathrm{z}$ Erdmannsdorf.

Pod koniec okresu panowania Fryderyka Wilhelma IV, który zmarł w 1861 roku, charakter regionu Kotliny Jeleniogórskiej zaczął ulegać dynamicznej zmianie, rodził się bowiem ruch turystyczny coraz szerszych warstw społecznych. Po połączeniu koleją Jeleniej Góry z Berlinem w 1866 roku i Wrocławiem w 1867 roku, Cieplice (niem. Bad Warmbrunn) stanowiące od XIV wieku rezydencję rodziny Schaffgotsch, straciły pozycję jedynego kurortu, gdyż cały region stał się łatwiej dostępny i zaczął ewoluować w kierunku funkcji wypoczynkowych.

Odkrycie dla kultury pruskiej, a później ogólno niemieckiej, Karkonoszy i ich podnóża, miało swego konkretnego i imiennego autora. Był nim Fryderyk (Friedrich) Wilhelm von Reden, który w roku 1785 nabył majątek ziemski w Bukowcu (niem. Buchwald), zbudował na nim pałac, i pod wyraźnym wpływem modnej wówczas brytyjskiej sztuki

\footnotetext{
${ }^{20} \mathrm{~W}$ tym samym roku na Śnieżkę wszedł późniejszy prezydent USA John Quincy Adams. Zob. R.M. Łuczyński Arystokratyczne podróże w rejon Kotliny Jeleniogórskiej w XIX wieku „Rocznik Jeleniogórski” 2007 nr XXXIX s. 113; A. Marsch, wyd. cyt. s. 20.

${ }^{21}$ Hans Dieter Rutsch, „Die Preussische Arkadien, Schlesien und die Deutschen“. 2014.

${ }^{22}$ Izabela Czartoryska, Dyliżansem przez Śląsk. Dziennik podróży do Cieplic w roku 1816, Wrocław 1968.

${ }^{23}$ W 1824 r. król pruski Fryderyk Wilhelm III nadał swej morganatycznej żonie Auguście von Harrach tytuł księżnej legnickiej (niem. Fürstin von Liegnitz) i hrabiny von Hohenzollern.
} 
ogrodowej, stworzył pierwszy w tym regionie park krajobrazowy w stylu angielskim ${ }^{24}$. Popularyzował także krajobraz tego regionu, organizując rysownikom berlińskiej KPM (Królewskiej Manufaktury Porcelany w Berlinie) warsztaty plenerowe wzorów malarskich przenoszonych potem na wyroby porcelanowe ${ }^{25}$.

Realizacja przez brata króla Prus, Wilhelma, w Górach Sokolich (niem. Valkenberg), obiektu myśliwskiego nazwanego od stylu szwajcarskiego Domek Szwajcarski (niem. Das Schweizer Haus) ${ }^{26}$, nie miała jeszcze większego znaczenia i publicznej ekspozycji z powodu trudno dostępnej lokalizacji.

Stała się jednak przełomem i świadectwem dostrzegania architektury wernakularnej przez pruską rodzinę królewską, przygotowała też przyjazną atmosferę dla eksperymentów z drewnem, m.in. K.F. Schinkel'a, który w swojej różnorodnej twórczości podejmował również próby budownictwa drewnianego, czego przykładem był pałacyk myśliwski jego autorstwa w Antoninie k. Poznania zrealizowany w latach 1821-182327.

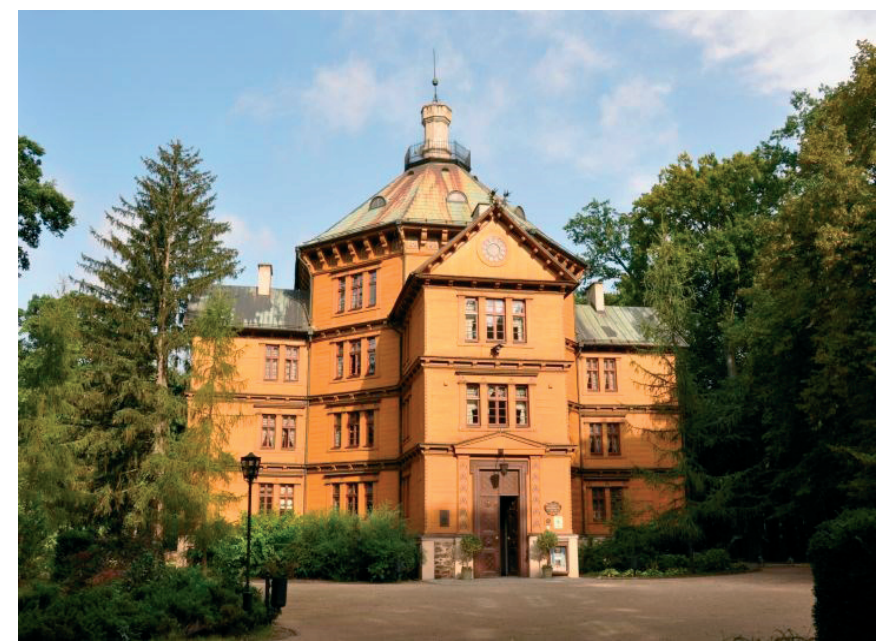

Fot. 5. Pałacyk Myśliwski Antoniego Radziwiłła, Antonin 1821 - 1823, autor K.F. Schinkel Autor fotografii: Grażyna Ruszczyk

${ }^{24}$ Motyw przekształcania terenów mało zagospodarowanych w artystyczny (,angielski”) park krajobrazowy, inspirowany dziełem Redena w Bukowcu, wplótł w świat przedstawiony swojej powieści „Powinowactwo z wyboru" zaprzyjaźniony z Redenem poeta Goethe.

${ }^{25}$ Friedrich Wilhelm von Reden (1752-1815) zakupił dobra Bukowiec w 1785 roku. Z pałacu uczynił swoją siedzibę i zaczął gromadzić dzieła sztuki, grafikę, porcelanę i odlewy żeliwne. W latach 1803-1807 pełnił urząd ministra górnictwa i hutnictwa w rządzie pruskim oraz dyrektora Königliches Porzellan Manufaktur w Berlinie, a pełnione funkcje wpłynęły znacząco na kształt jego kolekcji. Zbiory powiększały się w tym czasie znacząco ze względu na przysyłane do Redena duplikaty z KPM oraz odlewy żeliwne z zarządzanej przez niego huty gliwickiej.

${ }^{26}$ Nazwa gospody „Zur Schweizer Haus” jest oczywistym nawiązaniem do nazwy domku myśliwskiego „Das Schweizer Haus” (obie nazwy znaczą „Dom Szwajcarski”) znajdującego się nieopodal, a jej forma architektoniczna jest pokrewna zarówno pałacykowi myśliwskiemu, jak i stojącym obok domom Tyrolczyków. Dwoistość nazwy świadczy o utożsamianiu form tyrolskich i szwajcarskich. Valkenberg założone zostało przez ks. Marię Annę Amelie von Hessen-Homburg, Hohenzollern.

${ }^{27}$ Pałacyk w Antoninie - ośmioboczny korpus z czterema, nieco niższymi skrzydłami, tworzącymi wraz z nim plan krzyża, przykryty dachem namiotowym i dwuspadowymi. Oś kompozycyjną centralnej, trójkondygnacyjnej sali Schinkel oparł na centralnym filarze, podpierającym strop o promieniście ułożonych belkach. Podziały horyzontalne elewacji i mocno wysunięty okap dachu na wydatnych kroksztynach stanowią reminiscencję architektury włoskiej. Grażyna Ruszczyk Drewno i Architektura Arkady 2007. 
Wydarzeniem o doniosłych konsekwencjach dla architektury środkowoeuropejskiej i początkiem w Europie mody na użycie wzorców alpejskiej architektury wernakularnej, była jednak dopiero realizacja w roku 1837 projektu przekształcenia zespołu parkowopałacowego w Mysłakowicach (niem. Erdmannsdorf) u podnóża Karkonoszy w letnią rezydencję króla Prus Fryderyka Wilhelma III.

Ten położony w Kotlinie Jeleniogórskiej pałac, w miejscu, z którego rozpościera się widok na pasmo Karkonoszy ze Śnieżką ${ }^{28}$, król Prus kupił od spadkobierców hrabiego Gneisenau w 1831 roku i polecił głównemu architektowi Prus, K. F. Schinkel'owi, przebudować go na swą letnią rezydencję. Dla Schinkla stanowiło to logiczną ciągłość zawodową, gdyż motywy wernakularne w architekturze Europy Środkowej i Północnej popularyzował już w latach 20.tych i 30.tych XIX wieku, publikując projekty willi w ,guście” szwajcarskim $^{29}$.

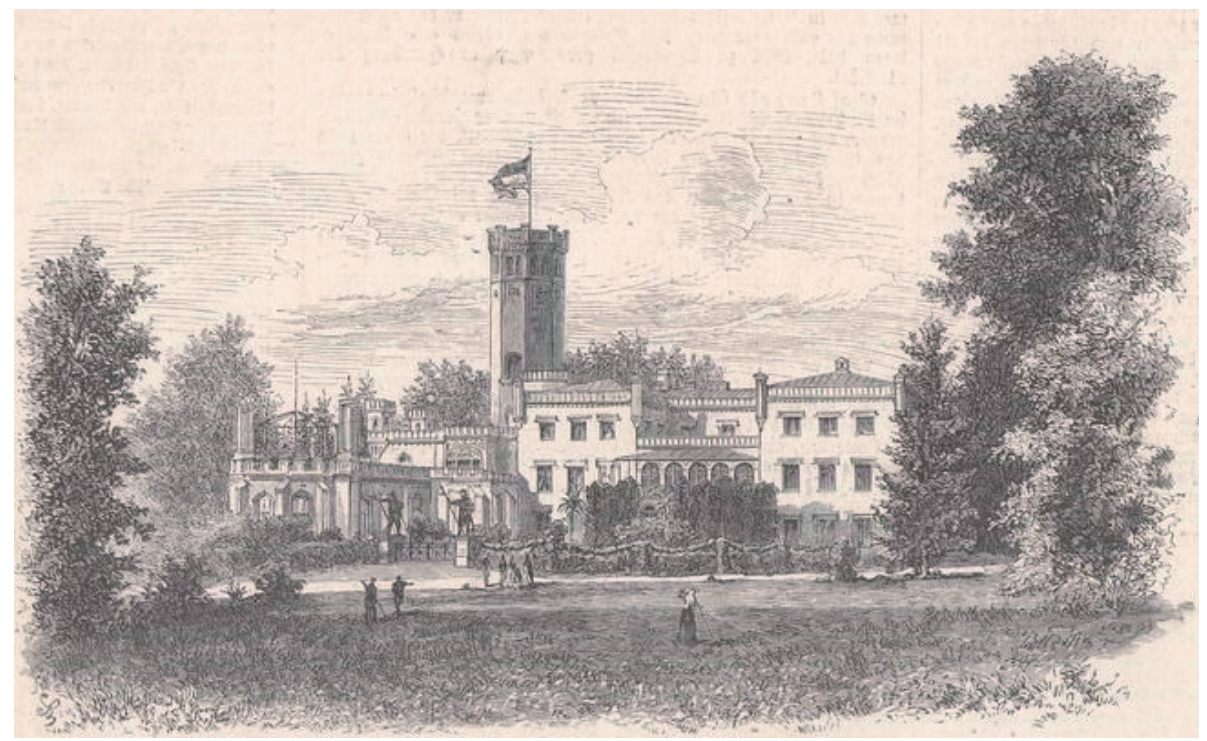

Ryc. 2. Pałac w Mysłakowicach (niem. Erdmannsdorf) na Śląsku. Widok z parku, Drzeworyt, karta pocztowa - fotografia J. Seifert, Jelenia Góra (niem. Hirschberg), ok. 1880 roku

Podjęte prace w Mysłakowicach (niem. Erdmannsdorf) nie były jeszcze ukończone, gdy społeczność tyrolskich chłopów z Zillerthal w Austrii zwróciła się do króla Prus z prośbą o zgodę na osiedlenie się u podnóża Karkonoszy, gdyż - jak pisali w liście do króla - krajobraz tego obszaru najbardziej przypomina im rodzinne strony ${ }^{30}$. Prawdziwym podłożem tej prośby była wprawdzie nietolerancja religijna, której Tyrolczycy jako protestanci doznawali ze strony cesarza Franciszka II w swej macierzystej Austrii, ale prośba ta została przez Fryderyka Wilhelma III. spełniona.

\footnotetext{
${ }^{28} \mathrm{~W}$ prasie popularnej przez dziesięciolecia krążyły relacje o wrażeniach na ten temat różnych wpływowych osób, na przykład o Alexandrze von Humboldcie, iż „kiedy stanął w parku w Mysłakowicach i spojrzał na Karkonosze, stwierdził, że jest to jeden z najpiękniejszych widoków na kuli ziemskiej”. Cyt. za: R. M. Łuczyński, wyd. cyt. s. 105.

${ }^{29}$ Grażyna Ruszczyk, Drewno i Architektura, Arkady 2007.

${ }^{30}$ Niemiecką nazwę - Erdmannsdorf, miejscowość zawdzięcza tyrolskim osadnikom z doliny Zillerthal, którzy osiedlili się tu z inicjatywy hrabiny Fryderyki Reden. Powodem, dla którego wyemigrowali oni z Tyrolu było prześladowanie w tym czasie protestantów w Austrii.
} 


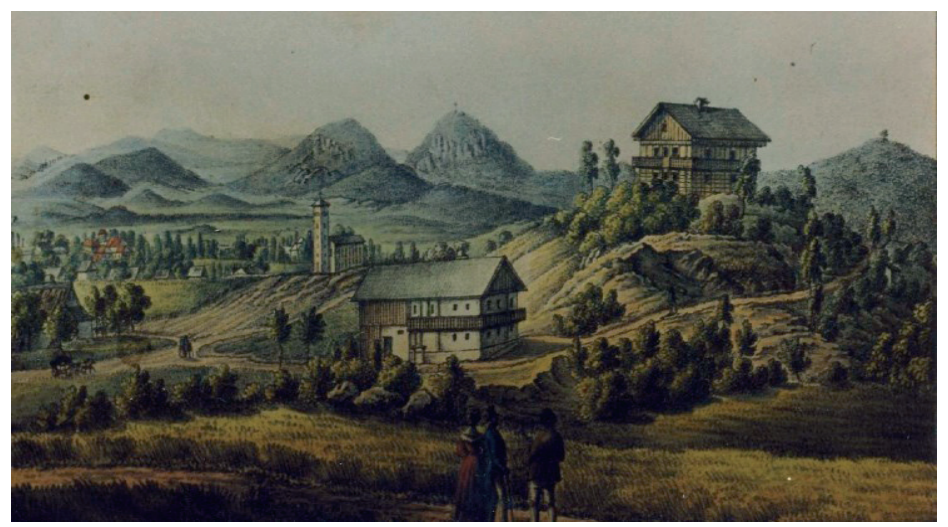

Ryc. 3. Obraz nieznanego autorstwa, przedstawiający założenie pałacowo - parkowe w Mysłakowicach (niem. Erdmannsdorf) ze zróżnicowaną funkcjonalnie zabudową wernakularną osadników tyrolskich

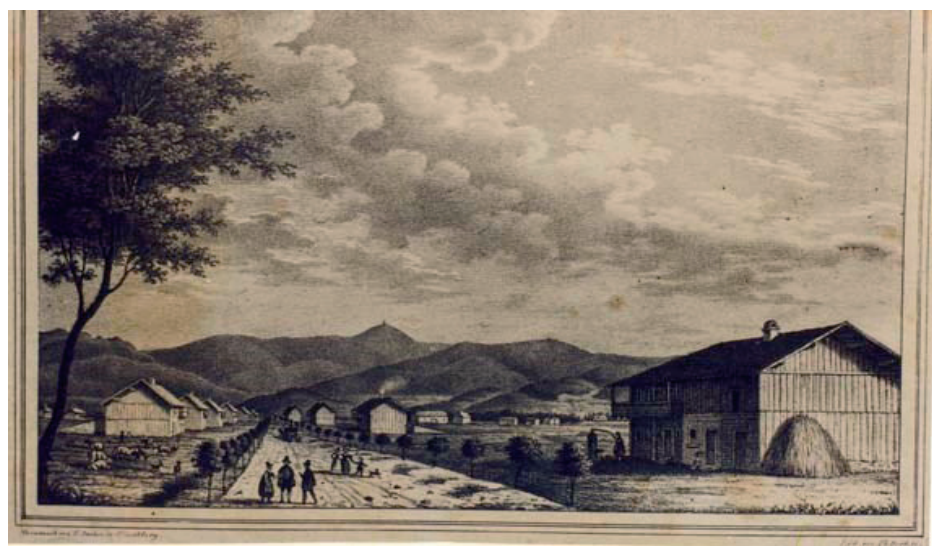

Ryc. 4. Obraz nieznanego autorstwa, przedstawiający zabudowę wernakularną osadników tyrolskich w Mysłakowicach (niem. Erdmannsdorf)

Nie do końca pewna jest w tym projekcie rola K. F. Schinkel'a; uważa się, że zaledwie wkomponował on w realizowany już projekt zabudowę zagrodową, wzbogacając $\mathrm{w}$ ten sposób angielską kompozycję parku krajobrazowego o modne wówczas elementy rustykalne, ale też mógł, jako współautor projektu kościoła i (niezrealizowanej) przebudowy królewskiego pałacu, uczestniczyć w planowaniu tyrolskiego osiedla. Prawdopodobnie o ostatecznym kształcie domów zdecydowali Tyrolczycy, którzy wznosili je sami, zgodnie z własną tradycją budowlaną, korzystając z pomocy miejscowych cieśli, co czyniłoby je wernakularnymi w formie czystej.

Z rustykalności i wernakularności założenia pałacowego użytek propagandowy zrobił zresztą sam Fryderyk Wilhelm III: osadnicy tyrolscy byli w końcu autentycznymi chłopami i rzemieślnikami, realnie gospodarowali a nie służyli jako dekoracja krajobrazowego parku pałacowego, zresztą częściowo go użytkując, a kościół położony w parku był ich kościołem parafialnym. Tym samym dokonała się nobilitacja, nienazwanej jeszcze wówczas, architektury wernakularnej.

Osiedlenie w Erdmannsdorf kolonii tyrolskich imigrantów zapewniało królowi Prus równocześnie kilka korzyści; po pierwsze estetyczną i modernizacyjną, gdyż standardy tyrolskie wprowadzały na ten teren nową jakość architektury i budownictwa, po drugie - 
zapewniało mu wdzięczność i lojalność nowych poddanych - osadników tyrolskich ${ }^{31}$, po trzecie dawało pozory egalitaryzmu i demokratyzacji życia publicznego, co po rewolucji francuskiej w ponapoleońskiej Francji z jednej strony, a z drugiej strony wobec zagrożenia niepokojami społecznymi po powstaniu listopadowym miało w Polsce niemałe znaczenie.

65 zrealizowanych wówczas w ramach tego projektu przez osadników tyrolskich domów / zagród uzupełniało założenie pałacowo-parkowe o pożądany element rustykalny zdecydowanie lepiej niż dość prymitywne lokalne budownictwo ludowe, w którym występowały trzy sposoby budowania: zrębowy, zrębowo-przysłupowy i fachwerkowy, ale domy były mniejsze od tyrolskich, miały węższe okapy i nie miały balkonów.

Jedynym odstępstwem od wernakularyzmu i dostosowaniem domostw Tyrolczyków do standardów lokalnego budownictwa Karkonoszy było nieznaczne podwyższenie dachów i zmiana ich pokrycia z dranic na gonty, na co ze względów pożarowych musieli skądinąd uzyskać zgodę administracji budowlanej ${ }^{32}$.

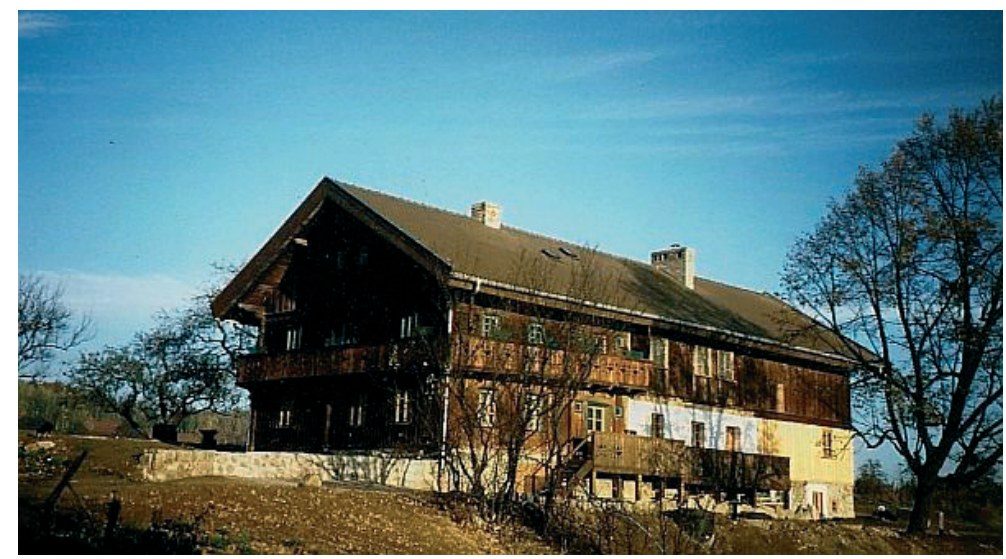

Fot. 6. Budynek o mieszanej mieszkalno-gospodarskiej funkcji w Erdmannsdorf, autor nieznany. Autor fotografii: nieznany

W sąsiedztwie pałacu w Erdmannsdorf wzniesione zostały cztery obiekty neowernakularne, stanowiące już nie kopię a rozwinięcie formy tyrolskich domów chłopskich. Pierwszym był pałacyk wzniesiony w latach 1838-1840 przez Chrystiana von Rother'a, ministra finansów nadzorującego przebudowę założenia pałacowo-parkowego, na wzgórzu położonym niedaleko pałacu ${ }^{33}$.

W Kotlinie Jeleniogórskiej pod koniec XIX wieku w szybkim tempie przybywało arystokratycznych pałaców w otoczeniu parkowym, jednak to Bukowiec (niem. Buchwald)

${ }^{31}$ Co wyrazili napisem wyciętym w balustradzie jednego z domów, znajdującej się obecnie w Muzeum Tyrolskim w Mysłakowicach: „Gott segne den König Friedrich Wilhelm III” („Boże błogosław Króla Fryderyka Wilhelma III").

32 tzw. kolonizacja fryderycjańska, 1740 - 1806, zakazująca wznoszenia tzw. kurnych chat. Nazwa pochodzi od króla Prus Fryderyka II, który w 1773 roku ogłosił edykt, w ramach którego każdy inwestor otrzymywał dotację pokrywającą niemal cały koszt budowy zagrody (murowanej), jako efekt rezygnacji $\mathrm{z}$ budowy budynku o konstrukcji z drewna.

${ }^{33}$ Jego nazwa historyczna to Schweizerhaus auf dem Rothersberge, zaś jego obecna polska nazwa to Czerwony Dworek (mieści się tam Monar). Autorstwo tego obiektu przypisywane jest K.F. Schinklowi (P. Napierała i A. Środek W Dolinie Pałaców i Ogrodów. Przewodnik, Wrocław 2010 s. 168). Wydaje się to prawdopodobne, jak i jego autorstwo pałacyku księżnej Legnicy, ale brak potwierdzenia tej informacji w materiałach źródłowych, co oczywiście jej nie zaprzecza. 
i Mysłakowice (niem. Erdmannsdorf) stanowią nieliczne przykłady kompozycyjnego powiązania architektury neowernakularnej z otoczeniem.

Radykalnie rosnące zapotrzebowanie na pensjonaty i hotele spowodowało konieczność wyboru stylu, form architektonicznych i materiałów, z jakich miałyby być realizowane; na podorędziu była jednak nadal gotowa do wykorzystania wernakularna tyrolska forma architektoniczna z Erdmannsdorf. Wkrótce stała się kopiowanym i przetwarzanym wzorcem dla budowli neowernakularnych, coraz częściej realizowanym w odmiennych technikach i materiałach, w fachwerku (murze pruskim) i murze litym. Styl ten, bo można w tym miejscu zacząć mówić o stylu, doczekał się również, w 1882 roku, pierwszej systematyki. ${ }^{34}$

Coraz rzadziej ten wernakularny wzorzec kopiowany był dosłownie. Powszechnie rezygnowano z bryły na rzucie prostokąta w konstrukcji zrębowej przekrytego dwuspadowym dachem krytym dranicami, na rzecz bardziej skomplikowanych form.

Po zmianie charakteru regionu, jaka nastąpiła w drugiej połowie XIX wieku, z obszaru rezydencjonalnego arystokracji pruskiej w region turystyki masowej oraz przemysłu włókienniczego ${ }^{35}$, ludowe budownictwo alpejskie stało się przedmiotem unowocześniających parafraz architektury pensjonatów, hoteli, domów kuracyjnych, schronisk etc. całego regionu Karkonoszy.

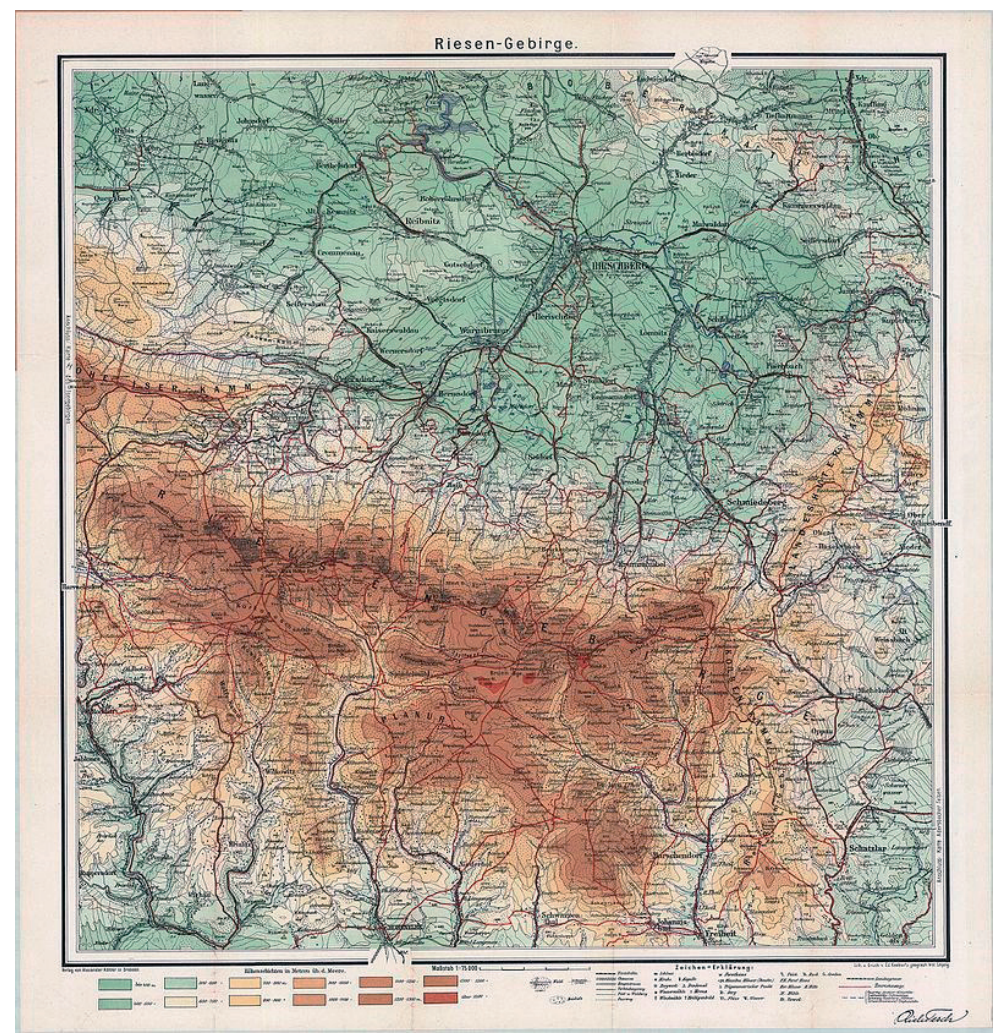

Ryc. 5. Mapa obszaru Kotliny Jeleniogórskiej (niem. Hirschberger Tal) na mapie z 1901 r. Widoczny na mapie Hirschberg to obecnie miasto Jelenia Góra

\footnotetext{
${ }^{34}$ Pierwszą próbą kodyfikacji architektury budownictwa alpejskiego była książka Ernsta Gladbacha Der Schweizer Holzstil (1882), a najstarszy przytoczony w niej przykład datowany jest na rok 1586.

${ }^{35}$ Przędzalnia lnu.
} 


\section{Wernakularyzm szwajcarski}

W przypadku rezydencji króla Prus - Fryderyka (Friedrich'a) Wilhelma III w Erdmannsdorf, dyskurs w kwestii stylu nie miał żadnego znaczenia i oczywistym jest, iż wpływów stylowych należało doszukiwać się w Tyrolu z powodu tyrolskich osadników, lecz w przypadku obiektów na terenach innych zaborów panowała pewna dowolność. W nomenklaturze polskiej, zasady nadawania nazewnictwa w zależności od kraju pochodzenia również nie była przestrzegane i miały na nie wpływ inne względy, także polityczne i patriotyczne. Proweniencja szwajcarska kojarzyła się lepiej niż pruska; po pierwsze neutralna Szwajcaria już wówczas stawała się mekką podróżników i eleganckim kurortem, w którym należało bywać, po drugie Tyrol nadmiernie kojarzył się z Niemcami, których ekspansjonizm zaczynał już być wkrótce, po utworzeniu w 1871 roku II Rzeszy, widoczny.

Neowernakularna architektura alpejska pojawiła się w Polsce początkowo w importowanej właśnie tyrolskiej a nie szwajcarskiej formie wernakularnej, dalekiej już formalnie i funkcjonalnie od wernakularnych pierwowzorów. Na początku pojawiła się w kurortach po węgierskiej (obecnie słowackiej) stronie Tatr, poczynając od Starego Smokowca (węg. Ótátrafüred, niem. Altschmeck), później w lokalizacjach podgórskich Tatr i Beskidów. W Zakopanem było podobnie: styl neo-alpejski pojawił się w formie już dojrzałej, eklektycznej, najpierw w dużym pensjonacie „Maryja” (obecnie Poraj) zbudowanym przy Krupówkach w roku 1887, autorstwa Fryderyka Kallaya, a wkrótce potem w obiektach podobnego typu.

Regionalnym szkołom rzemiosła władze austriackie wyznaczyły ważną rolę w ujednolicaniu twórczości ludowej w całym państwie Habsburgów; podstawą było nauczanie rzemiosła bazującego na formach tyrolskich, jedynie z domieszką form lokalnych. Kolejni dyrektorzy szkoły - Franz Neužil i Edgar Kovats, oraz niektórzy jej nauczyciele, byli architektami przygotowanymi do krzewienia budownictwa neo-alpejskiego na terenach polskich - etnicznie obcych, o odmiennej tradycji ludowej. Nic zatem dziwnego, że pierwszy nowoczesny obiekt - Pensjonat „Maryja”, nawiązywał do budownictwa tyrolskiego, a nie podhalańskiego.

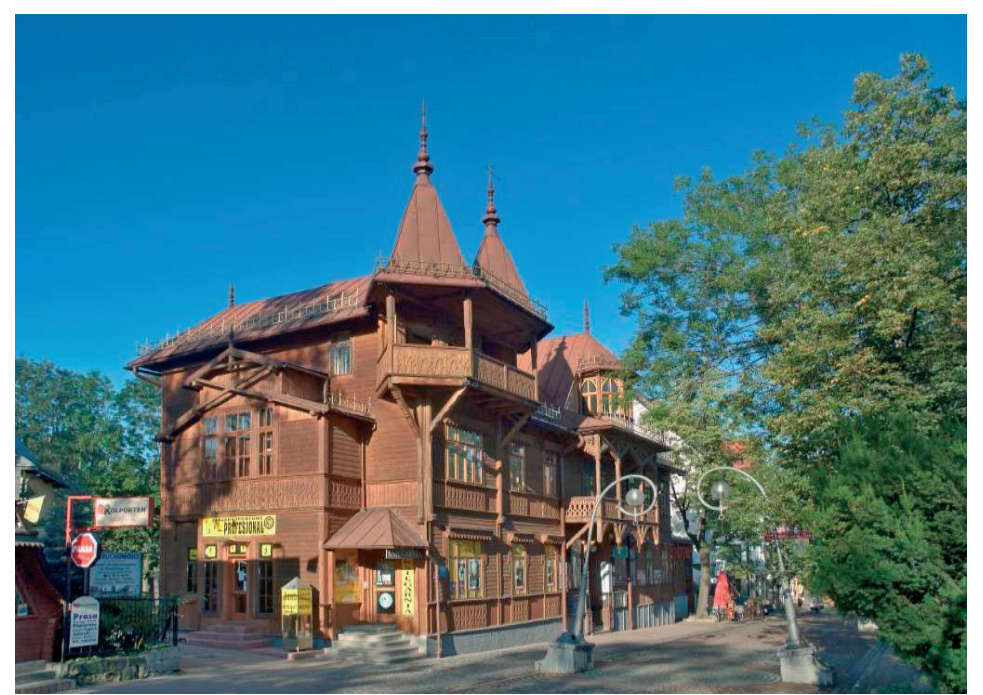

Fot. 7. Willa „Maryja” przy Krupówkach w Zakopanem, wybudowana dla Marii Makswald w 1887 r., proj. Fryderyk Kallay, autor fotografii nieznany 
W miarę przekształcania się w Szwajcarii wzorca architektonicznego z wernakularnego w neowernakularny, również w Polsce zachodziła podobna jego ewolucja. Z pewną przesadą można uznać, iż architektura ta czerpiąc z architektury neowernakularnej pruskich Karkonoszy, w Polsce stała się wtórnie neowernakularna. W Zakopanem styl neo-tyrolski stał się celem ataku ze strony patriotycznie orientowanej inteligencji i bohemy, inspirowanej przez Stanisława Witkiewicza, lansującego styl alternatywny wobec „tyrolszczyzny”, wzorowany na budownictwie górali nie alpejskich a podhalańskich.

Zwycięstwo nad stylem tyrolskim spowodowało, iż styl zakopiański stał się wykreowanym, czasami nieco na siłę a czasami wbrew logice budowlanej ${ }^{36}$, na zamówienie narodowe czy społeczne, odrębnym stylem architektoniczno-budowlanym. Nadało to Zakopanemu i regionowi Podhala, oraz kurortom takim jak Cieplice czy Karpacz, tożsamość architektoniczną utrzymującą się do współczesności.

Krajobraz Polski w zakresie architektury ludowej, w okresie zaborów kształtowały nie tylko lokalne tradycje i importowany tyrolski styl neowernakularny, ale również standardy i przepisy budowlane obowiązujące w państwach zaborców. Przepisy takie odgrywały coraz istotniejszą rolę w umacniających się i coraz bardziej opresyjnych administracjach centralnych. Nowelizacja przepisów i rozwój ustawodawstwa budowlanego o jurysdykcji poszerzanej poza granice i problematykę miast, uwzględniającej oprócz kwestii przeciwpożarowych także problemy sanitarne, bezpieczeństwo i higienę życia a także obejmującej zagadnienia planowania przestrzennego estetykę budowli, związane było z industrializacją .

Wiele przepisów bezpośrednio lub pośrednio dotyczyło stosowania drewna w budownictwie, które starano się ograniczyć, początkowo jedynie w pokryciach dachowych, później również w konstrukcji ścian. Jak w przypadku Erdmannsdorf, tak w całym zaborze pruskim, już od 1773 roku obowiązywał zakaz stosowania konstrukcji zrębowej. Procesowi eliminacji drewnianego budulca służyły zarówno odpowiednie przepisy jak i polityka podatkowa i ubezpieczeniowa, polegająca na stosowaniu zachęcających inwestorów obniżek stawek dla inwestorów stosujących materiały ogniotrwałe. Rozwój przepisów w każdym państwie przebiegał w innym tempie; najbardziej postępowe, czyli rygorystyczne wobec inwestorów i sprawnie egzekwowane, obowiązywały w Prusach ${ }^{37}$, liberalniejsze w Austrii ${ }^{38}$, a najłagodniejsze - w Rosji ${ }^{39}$.

Można mieć wątpliwości, czy ze względu na pozycję społeczną i polityczną inwestorów, tak jak w przypadku myśliwsko - rekreacyjnych budowli hr. Potockiego w Łańcucie, ks. A. Radziwiłła w Antoninie, ale i innych obiektów, głównie pensjonatowych obiektów neowernakularnych ${ }^{40}$, mogły takim restrykcjom w zakresie stosowania konstrukcji drewnianej w ogóle podlegać, faktem jednak jest, że drewniana technologia architektury neowernakularnej stała się wkrótce niezgodna z obowiązującymi przepisami budowlanymi ${ }^{41}$.

\footnotetext{
36 - co dotyczyło głównie pokryć dachowych i spadków dachu oraz odporności ogniowej.

${ }^{37}$ tzw. kolonizacja fryderycjańska, $1740-1806$, zakazująca wznoszenia tzw. kurnych chat.

${ }^{38}$ tzw. kolonizacja józefińska, której inicjatorem był cesarz Austrii, Józef II.

39 od połowy XIX wieku zaczął obowiązywać na terenie Królestwa Polskiego zakaz wznoszenia budynków wykonywanych z drewna, jednak nie był przestrzegany bezwzględnie. Na terenie monarchii Habsburgów, od 1889 r. obowiązywała Ustawa budownicza dla znaczniejszych miejscowości w Królestwie Galicji i Lodomerii wraz z Wielkim Księstwem Krakowskim z dnia 4 kwietnia 1889 r. (Dz. Ust. i Rozp. Kr. dla Kr. G. i L. z W. Ks. Kr. Nr 31 z 1889 r., Nr 70 z 1898 r. i Nr 56 z 1907 r.) oraz Ustawa budownicza dla wsi i pomniejszych miast i miasteczek z dnia 13 października 1899 r. (Dz. Ust. i Rozp. Kr. dla Kr. G. i L. z W. Ks. Kr. Nr 133 z 1899 r., Nr 57 z 1907 r. i Nr 91 z 1909 r.

40 Pałacyk Myśliwski w Julinie, zrealizowany w $1880 \mathrm{r}$.

${ }^{41}$ Łukasz Opaliński, marszałek nadworny i koronny, „Krótka nauka budowania dworów, pałaców y zamków podług nieba y zwyczaju polskiego”, 1659 r., podręcznik dla „możnych panów”, w którym utożsamia architekturę rodzimą z architekturą drewnianą. Zbiory Biblioteki Kórnickiej.
} 


\section{Literatura}

1. Beylin K. Dni powszechne Warszawy w latach 1880-1890.

2. Czartoryska I. Dyliżansem przez Śląsk. Dziennik podróży do Cieplic w roku 1816, Wrocław 1968.

3. Frampton K. Towards a Critical Regionalizm: Six points of an architecture of resistance. [w:] The Anti-Aesthetic (red.) H. Forster, Port Townsend 1983.

4. Gladbach E. Der Schweizer Holzstil. 1882.

5. Koolhaas R. Content. 2004, Rem Koolhaas

6. Kurzątkowski M. Architecture vernaculaire = architektura rodzima. Ochrona Zabytków 1 (158) 3 .

7. Łuczyński R.M. Arystokratyczne podróże w rejon Kotliny Jeleniogórskiej w XIX wieku. Rocznik Jeleniogórski XXXIX 2007.

8. Marsch A. wyd. cyt. s. 54, 56, 60.

9. Oktabiński K. Michat Elwiro Andriolli - artysta poludniowo-wschodniego Mazowsza. Otwockie Towarzystwo Naukowo-Kulturalne.

10. Miłobędzki A. Zarys dziejów architektury w Polsce. 1989, Wydawnictwo: Wiedza Powszechna.

11. Oliver P. Encyclopedia of Vernacular Architecture of the World. 1997 Vol. 1 Theories and Principles, 1998, Cambridge University Press.

12. Opaliński Ł. Krótka nauka budowania dworów, pałaców y zamków podtug nieba y zwyczaju polskiego. 1659 r., Zbiory Biblioteki Kórnickiej.

13. Pawlicki B.M. Architektura bez granic - peryferyjność czy uniwersalizm. Zakład Studiów i Badań Konserwatorskich, Instytut Historii Architektury i Konserwacji Zabytków, 2007, Politechnika Krakowska.

14. Pyzik E. Historia Erdmannsdorf - Zillerthal - Mysłakowic 1385 -1945. Mysłakowice 19902000, Cyfrowy Dolny Śląsk.

15. Rudofsky B. Metropolitan Museum of Modern Art. 1964. Pod tym samym tytułem co wystawa - wydana książka, autorstwa Rudofsky B. Encyklopedia architektury wernakularnej świata. 1997, pod red. Paula Olivera, New York.

16. Ruszczyk G. Drewno i Architektura. 2007, Arkady.

17. Rutsch H.D. Die Preussische Arkadien, Schlesien und die Deutschen. 2014.

18. Rytel G. Wernakularna czyli jaka? Uwagi semantyczne na marginesie tematu konferencji. Budownictwo i Architektura 14(3) (2015) 143-149.

19. Steffens M. K.F. Schinkel, 1781-1841: An Architect in the Service of Beauty.

20. Tarnowski J. Styl alpejski w Środkowej Europie i polska kontrakcja wobec niego - styl zakopiański, Estetyka i Krytyka.

21. Turkušić E. Neo-vernacular architecture - contribution to the research on revival of vernacular heritage through modern architectural design. 2011, Conference: Importance of Place - 4th International Conference on Hazards and Modern Heritage, University of Sarajevo.

22. Ustawa budownicza dla znaczniejszych miejscowości w Królestwie Galicji i Lodomerii wraz z Wielkim Księstwem Krakowskim z dnia 4.04. 1889 r. (Dz. Ust. i Rozp. Kr. dla Kr. G. i L. z W. Ks. Kr. Nr 31, 1889 r., Nr 70 z 1898 r., Nr 56 z 1907 r.).

23. Ustawa budownicza dla wsi i pomniejszych miast i miasteczek z dnia 13 października $1899 \mathrm{r}$. (Dz. Ust. i Rozp. Kr. dla Kr. G. i L. z W. Ks. Kr. Nr 133 z 1899 r., Nr 57 z 1907 r. i Nr 91 z $1909 \mathrm{r}$.

24. Węcławowicz-Gyurkovich E. Postmodernizm w polskiej architekturze. Kraków 1998.

25. Wiercińska J. Andriolli, świadek naszych czasów-listy i wspomnienia. Wrocław 1976. 


\title{
Neovernacular architecture - genesis. From Erdmannsdorf to Pension „Maryja”
}

\author{
Jacek K. Knothe \\ Department of Conservation of Built Heritage, Lublin University of Technology, \\ e-mail:j.knothe@pollub.pl
}

\begin{abstract}
Being on the edge of architecture created by architects, vernacular architecture always remained the margin. While it was never in collision with the main stream, it was rather an independent movement, occurring and proceeding with the rhythm and pace of its own.

It is called vernacular, deriving from ,vernaculus" in latin, and meaning ,native”. The term does not exhaust the complexity of the issue; there is though a substantial difference between vernacular architecture, the vernacular phenomenon as such, and above all, the neovernacularism.
\end{abstract}

It is assumed, that vernacular architecture means ,the architecture without the architect, anonymous, arising beyond the design process, constituting part of tradition of society and being the sum of building, functional and esthetic experience that is being passed from generation upon generation". Question is remaining, whether ,arising beyond the design process" means, that vernacular architecture has aroused in the past beyond the design process. If so, it would make it vernacular.

If it meant though, that architecture was being currently created without the design process, it would make it neovernacular.

Polish theorists and historians recognize the problem of vernacular architecture based on different approach; Miłobędzki, A., emphasises local building tradition and the use of local building materials, as being crucial, while Fiett, J., places vernacular architecture between primitive and authorial architecture, emphasizing the aspect of copying and replicating of a specific archetype that is considered an object of art.

None of the above authors regards, and even less evaluates, the absolute virtues of vernacular architecture, surprisingly at the same time considering its repetitiveness and regarding it as being equally authentic as the vernaculate original.

While copying the historical origin, seen as a piece of art, vernacular architecture itself deserves no such name. With due respect for its artistic and historical values and undoubtful charm, neovernacular architecture deserves such merit even less.

Simplifying matters, vernacular architecture is, by some, viewed simply equal to regional building. Based on the fact, that it constitutes a work of the authors with no academic background, it is regarded a building process that freely benefits from vernacular architecture, with no specific differentiation between conservational and interpretive neovernacularism. The first means nothing else than the continuity of action of our predecessors, i.e. the maintainance and the use of traditional building techniques and materials, the second assumes the adoption of vernacular architecture to new functions and uses, making it thus neovernacular.

It is the intention of the author to show the origins of the vernacular architecture in Central Europe, including Poland, as deriving from Swiss origin.

Keywords: Gründerzeit, Gründer, historism, eclectism, neostyle, vernacular, neovernacular. 